\title{
Lentilactobacillus hilgardii Inoculum, Dry Matter Contents at Harvest and Length of Conservation Affect Fermentation Characteristics and Aerobic Stability of Corn Silage
}

\author{
Francesco Ferrero*, Ernesto Tabacco and Giorgio Borreani \\ Department of Agricultural, Forestry and Food Sciences, University of Turin, Turin, Italy
}

\section{OPEN ACCESS}

Edited by:

Jin Zhong,

Institute of Microbiology Chinese Academy of Sciences (CAS), China

Reviewed by: Ana Griselda Binetti, Universidad Nacional del Litoral (FIQ-UNL), Argentina Carla Ávila,

Universidade Federal de Lavras, Brazi

${ }^{*}$ Correspondence:

Francesco Ferrero francesco.ferrero@unito.it

Specialty section:

This article was submitted to

Microbiotechnology,

a section of the journal

Frontiers in Microbiology

Received: 03 March 2021 Accepted: 03 May 2021

Published: 02 June 2021

Citation:

Ferrero F, Tabacco E and Borreani G (2021) Lentilactobacillus hilgardii Inoculum, Dry Matter

Contents at Harvest and Length of Conservation Affect Fermentation Characteristics and Aerobic Stability of Corn Silage.

Front. Microbiol. 12:675563. doi: 10.3389/fmicb.2021.675563
Heterofermentative Lentilactobacillus hilgardii isolated from sugarcane silage, has recently been proposed as a silage inoculant to increase aerobic stability. Various conditions can influence the activity of $\angle A B$ and their ability to alter silage quality (e.g., DM content and length of conservation). The aim of this study has been to evaluate the effect of $L$. hilgardii on the fermentation quality and aerobic stability of whole crop corn silage with different DM contents (from 26 to $45 \%$ ), conserved for various conservation lengths (13-272 days). The silages were analyzed for their DM content, $\mathrm{pH}$, fermentative profile, microbial count, and aerobic stability. L. hilgardii showed a positive effect on improving the aerobic stability of silages, due its ability to produce acetic acid, and reduced the yeast count. The acetic acid content increased as the conservation period increased and decreased as the DM content increased. The yeast count was reduced during conservation in a DM dependent manner and the inoculation with $\mathrm{LH}$ determined a reduction in the count of $0.48 \mathrm{log} \mathrm{cfu} / \mathrm{g}$. The aerobic stability increased as the conservation period increased, and the treatment with LH on average increased the aerobic stability by $19 \mathrm{~h}$. The results of this experiment suggest that higher aerobic stability could be achieved in corn silages by ensiling at medium or low DM contents, or by increasing the length of conservation if a higher DM content at ensiling is needed. The inoculation with LH helps to improve the aerobic stability of corn silages by reducing the yeast count.

Keywords: dry matter, inocula, yeast count, conservation time, aerobic stability

\section{INTRODUCTION}

The presence of spoiled silages on a farm is a challenge, and it results in a reduction of the nutritive value of the silage and an increase in the risks to animals and humans (Driehuis et al., 2018). During the feed-out phase, the contact of the mass with air stimulates the growth of the aerobic microorganisms that are most often responsible for the onset of aerobic instability (Borreani et al., 2018). Aerobic deterioration is common in many silages that are opened and exposed to air, with the rate of spoilage being highly dependent on the numbers and activity of the spoilage organisms in the silage and on the fermentative profile of the silo at opening (Muck et al., 2018). It is generall 
accepted that yeasts play the major role in initiating aerobic spoilage (Pahlow et al., 2003) and the aerobic stability of corn silage has been found to be closely correlated with the number of yeasts (Borreani et al., 2018). Therefore, a fermentative profile with antifungal compounds may be beneficial to avoid aerobic deterioration. Acetic acid has been reported to be an effective compound that improves aerobic stability by reducing yeasts during conservation and by limiting their growth after silage is exposed to air (Kleinschmidt and Kung, 2006; Comino et al., 2014; Ferrero et al., 2019). In the last 20 years, heterofermentative lactic acid bacteria (LAB), and Lentilactobacillus buchneri (previously classified as Lactobacillus buchneri, Zheng et al., 2020) in particular, have been used as inocula to prevent the aerobic deterioration of silages, because of their ability to produce acetic acid via the anaerobic conversion of moderate amounts of lactic acid to acetic acid and 1,2-propanediol (Oude Elferink et al., 2001; Muck et al., 2018). However, different conditions can influence the activity of LAB and their ability to alter silage quality (Muck et al., 2018), and heterofermentative LAB inoculants have not been consistently effective in improving aerobic stability as a result of the type of forage, the dry matter $(\mathrm{DM})$ of the forage at harvest, variations in the application rate, and the temperature and length of conservation (Kleinschmidt and Kung, 2006; Blajman et al., 2018; Ferrero et al., 2021). Silages with a high DM content (e.g., >38\%) are more prone to aerobic spoilage than those with a low content, because the LAB activity is limited by the reduced water activity $\left(a_{w}\right)$ and, consequently, the production of acids is low (Comino et al., 2014). The length of conservation represents a critical point for the quality and stability of silage. A long conservation period in complete anaerobiosis determines a decrease in the microbial count and in particular in the yeast and mold counts, and consequently improves the aerobic stability of silages, regardless the use of silage inocula (Weinberg and Chen, 2013; Ferrero et al., 2019). L. buchneri-based inocula often need a long conservation period ( $>45$ to 60 days) to be efficacious (Driehuis et al., 1999). Producers often want to start feeding-out silages from silos after ensiling periods of less than 30 days, thus making it necessary for the acetic acid to be produced earlier by heterofermentative LAB, during ensiling (Ferrero et al., 2019; Nair et al., 2020). Lentilactobacillus hilgardii (previously classified as Lactobacillus hilgardii, Zheng et al., 2020), was isolated from sugar cane (Ávila et al., 2014) and deposited and patented as silage inocula (European Patent Application EP2826385A1), thereby becoming a possible new inoculum to improve aerobic stability after a short conservation period. Phylogenetic evaluation and fermentation profiling of $L$. hilgardii have revealed that it is closely related to L. buchneri, as both possess the ability to degrade lactic acid to acetic acid and to 1,2-propanediol in anaerobic conditions (Heinl et al., 2012; Drouin et al., 2019). Assis et al. (2014) gave the first indication of the use of L. hilgardii as inoculum for corn silage. Subsequent studies were conducted to evaluate the impact of L. hilgardii on ensiling fermentation and on the aerobic stability of corn silages, and they reported higher concentrations of acetic acid, lower yeast populations, and a higher aerobic stability than uninoculated silages (Reis et al., 2018; Ferrero et al., 2019; Costa et al., 2021).
Since the DM content at harvest and the length of conservation can affect the silage quality and the effectiveness of inocula, the aim of this study has been to evaluate the effects of L. hilgardii, the DM content at harvest and the length of conservation on the fermentation quality and aerobic stability of whole crop corn silages.

\section{MATERIALS AND METHODS}

\section{Crop and Ensiling}

Thirteen dairy farms operating in the western Po plain, northern Italy, were involved in the research. Each farm was asked to grow the same corn hybrid (Zea mays L. cultivar P1517W, Pioneer Hi-Bred Italia Srl, Gadesco Pieve Delmona, Cremona, Italy) and to manage the crop in almost the same agronomic way. Briefly, seeding date in the first decade of April; theoretical planting density of 75,000 seeds/ha; conventional tillage at $0.25-0.30 \mathrm{~m}$ depth; fertilization with 20,000-30,000 kg/ha of liquid slurry (average NPK content of $0.27,0.24$, and $0.31 \%$ on fresh basis) applied immediately before plowing, $104 \mathrm{~kg} / \mathrm{ha}$ of potassium chloride $(\mathrm{K}, 60 \%)$ applied prior to planting, $104 \mathrm{~kg} / \mathrm{ha}$ of diammonium phosphate (NP, 18 and 46\%) applied at planting, and $166 \mathrm{~kg} / \mathrm{ha}$ of urea $(\mathrm{N} \mathrm{46 \% )}$ top dressed at the 6-8 leaf-stage; pre-emergence weed control with Lumax (mesotrione $37.5 \mathrm{~g} / \mathrm{l}$, S-metolachlor $37.5 \mathrm{~g} / \mathrm{l}$ and terbuthylazine, $12.5 \mathrm{~g} / \mathrm{l}$, Syngenta, Basel, Switzerland) at a rate of $3.5 \mathrm{l} /$ ha plus an additional postemergence application with Titus ${ }^{\S}$ Mais Extra (nicosulfuron $300 \mathrm{~g} / \mathrm{kg}$, rimsulfuron $150 \mathrm{~g} / \mathrm{kg}$, DuPont, Milano, Italy) at a rate of $70 \mathrm{~g} / \mathrm{ha}$, if necessary; 3-5 irrigations (flooding method, about 200-300 $\mathrm{mm}$ each time). In each farm (except one) the crop was harvested at two different maturity stages of growth to obtain different DM contents at ensiling. Corn was harvested, as chopped whole crop, using a precision forage harvester (Claas Jaguar 950, equipped with an 8-row Orbis head, Claas, Harsewinkel, Germany) to a theoretical cutting length of $12 \mathrm{~mm}$. The DM contents of the forages at harvest ranged from 25 to $45 \%$. The field was divided into blocks, which were subsequently harvested separately to obtain three replicates. The fresh herbage of each plot was divided into two piles (about $50 \mathrm{~kg}$ ), which were either not treated, as a negative control (CONT), or treated with Lentilactobacillus hilgardii CNCM I-4785 (Lallemand SAS, France) at 300,000 cfu/g fresh matter (FM) (LH). The lyophilized microbial inoculant was diluted in sterilized water and applied using a hand sprayer, at a rate of $4 \mathrm{~mL} / \mathrm{kg}$ of forage, by spraying uniformly onto the forage, which was constantly hand mixed. The same amount of water was added to the CONT treatment. In order to add the targeted amount of LAB, the inoculum was plated on MRS agar (Merck, Whitehouse Station, NY), to which natamycin $(0.25 \mathrm{~g} / \mathrm{L})$ had been added and incubated as described hereafter. Moreover, an appropriate amount of inoculum was used, on the basis of the measured LAB concentration, to achieve the desired application rate.

The fresh forage was sampled prior to ensiling after the inoculum had been applied. The untreated and treated forages were then ensiled (about 10-14 kg of wet forage) in $20 \mathrm{~L}$ plastic silos equipped with a lid that only enabled the release of gas. 
The forages were packed by hand in order to reach the same weight of the silo at similar DM contents. Therefore, the final packing densities, on a wet basis, ranged from 669 to $529 \mathrm{~kg}$ $\mathrm{FM} / \mathrm{m}^{3}$ depending on DM content. All the laboratory silos were filled within $3 \mathrm{~h}$. The silos were weighed and conserved at ambient temperature in a controlled environment $\left(20 \pm 1^{\circ} \mathrm{C}\right)$ and were then opened after a conservation period ranging from 13 to 272 days, depending on the experiment. On opening, each silo was weighed again, the first $50 \mathrm{~mm}$ layer was discarded, and the remaining silage was mixed thoroughly and subsampled to determine the DM content, chemical composition, fermentation profile and the microbial counts. The DM losses due to fermentation were calculated as the difference between the weight of the forage placed in each plastic silo at ensiling and the weight of the silage at the end of conservation, corrected for the DM content of the forage and its respective silage.

After sampling, the silages were subjected to an aerobic stability test, which involved monitoring the temperature increases due to the microbial activity in the samples exposed to air in insulated boxes under a controlled environment. About $3 \mathrm{~kg}$ from each silo was allowed to aerobically deteriorate at a controlled temperature $\left(20 \pm 1^{\circ} \mathrm{C}\right)$ in $17 \mathrm{~L}$ polystyrene boxes (290 $\mathrm{mm}$ diameter and $260 \mathrm{~mm}$ height). A single layer of aluminum foil was placed over each box to prevent drying and dust contamination, but also to allow the air to penetrate. The room and silage temperatures were measured hourly by means of a mini temperature logger (Escort Intelligent Mini, Escort Data Logging Systems Ltd., Auckland, New Zealand). Aerobic stability was defined as the number of hours the silage remained stable before its temperature increased by $2^{\circ} \mathrm{C}$ above the ambient temperature.

\section{Sample Preparation and Analyses}

The pre-ensiled material and the silages were split into five subsamples. One sub-sample was analyzed immediately, for the $\mathrm{DM}$ content, by oven drying at $80^{\circ} \mathrm{C}$ for $24 \mathrm{~h}$. Dry matter was corrected according to Porter and Murray (2001), to consider the volatile compound losses that can take place at $80^{\circ} \mathrm{C}$. The second subsample was oven-dried at $65^{\circ} \mathrm{C}$ to a constant weight and was air equilibrated, weighed and ground in a mill (Cyclotec Tecator, Herndon, VA, United States) to pass a $1 \mathrm{~mm}$ screen. The dried samples were analyzed for the total nitrogen (TN), according to the Dumas method (method number 992.23, AOAC International, 2005), using a Primacs SN nitrogen analyzer (Skalar, Breda, The Netherlands), for crude protein (CP) (total $\mathrm{N} \times 6.25$ ) and for ash by ignition (method number 942.05, AOAC International, 2005). The starch concentration was determined according to the AOAC methods (method number 996.11; AOAC International, 2005). Neutral detergent fiber (NDF) was analyzed, using a Raw Fiber Extractor (FIWE, VELP Scientifica, Usmate Velate, Italy), with the addition of heat-stable amylase (A3306, Sigma Chemical Co., St. Louis, MO) and expressed on a $\mathrm{DM}$ basis, including residual ash, as described by Van Soest et al. (1991). Acid detergent fiber (ADF) was analyzed and expressed on a DM basis, including residual ash (Robertson and Van Soest, 1981). A third fresh sub-sample was used to determinate the water activity $\left(\mathrm{a}_{\mathrm{w}}\right), \mathrm{pH}$, nitrate $\left(\mathrm{NO}_{3}\right)$ and the buffering capacity. $\mathrm{a}_{\mathrm{w}}$ was measured at $25^{\circ} \mathrm{C}$, on a fresh sample, using an AquaLab Series 3TE (Decagon Devices Inc., Pullman, WA), which adopts the chilled mirror dew point technique. The fresh forage was extracted for $\mathrm{pH}$ and nitrate using a Stomacher blender (Seward Ltd., Worthing, United Kingdom), for $4 \mathrm{~min}$ in distilled water at a 9:1 water-to-sample material (fresh weight) ratio. The total nitrate concentration was determined in the water extract, through semi-quantitative analysis, using Merckoquant test strips (Merck, Darmstadt, Germany; detection limit $100 \mathrm{mg} \mathrm{NO} / \mathrm{kg}$ $\mathrm{DM}$ ). The $\mathrm{pH}$ was determined using a specific electrode (DL21 Titrator, Mettler Toledo, Milan, IT). The buffering capacity was determined in the water extract, as described by Playne and McDonald (1966). A fourth sub-sample was extracted, using a Stomacher blender, for $4 \mathrm{~min}$ in $\mathrm{H}_{2} \mathrm{SO}_{4} 0.05 \mathrm{~mol} / \mathrm{L}$ at a $4: 1$ acidto-sample material (fresh weight) ratio. An aliquot of $40 \mathrm{~mL}$ of silage acid extract was filtered with a $0.20-\mu \mathrm{m}$ syringe filter and used for quantification of the fermentation products. The lactic and monocarboxylic acids (acetic, propionic and butyric acids) were determined, by means of high-performance liquid chromatography (HPLC), in the acid extract (Canale et al., 1984). Ethanol and 1,2-propanediol were determined, by means of HPLC, coupled to a refractive index detector, on a Aminex HPX$87 \mathrm{H}$ column (Bio-Rad Laboratories, Richmond, CA). The fifth subsample was used for the microbial analyses.

In order to conduct the microbial counts, an aliquot of $30 \mathrm{~g}$ was transferred into a sterile homogenization bag, suspended 1:9 $\mathrm{w} / \mathrm{v}$ in a peptone salt solution ( $1 \mathrm{~g}$ of bacteriological peptone and $9 \mathrm{~g}$ of sodium chloride per liter) and homogenized for $4 \mathrm{~min}$ in a laboratory Stomacher blender (Seward Ltd., London, United Kingdom). Serial dilutions were prepared, and the yeast and mold numbers were determined using the pour plate technique by inoculating, in duplicate, $1 \mathrm{~mL}$ of dilution on Yeast Extract Glucose Chloramphenicol Agar (YGC agar, DIFCO, West Molesey, Surrey, United Kingdom), after incubation at $25^{\circ} \mathrm{C}$ for 3 and 5 days for yeast and mold, respectively. The yeast and mold colony forming units ( $\mathrm{cfu}$ ) were enumerated separately, according to their macromorphological features, on plates that yielded 15-150 cfu. Since lot of samples had very low yeast and mold counts, when the plates of the original dilution yielded fewer than 15 colonies, actual plate count was recorded and reported as $\log$ transformed value. A detection limit of $1.00 \mathrm{log}$ $\mathrm{cfu} / \mathrm{g}$ (10 cfu/g of silage) has been assumed when plates from original dilution yielded no colony forming unit. The LAB counts were determined on MRS agar, to which natamycin $(0.25 \mathrm{~g} / \mathrm{L})$ had been added, by incubating the Petri plates at $30^{\circ} \mathrm{C}$ for 3 days in anaerobic jars with a gas generating system [AnaeroGenTM, Thermo Fisher Scientific, Rodano (MI), Italy]. Since LAB are facultative anaerobe bacteria, anaerobic incubation was chosen to improve the selectivity of the media against Bacillus spp. (Spoelstra et al., 1988). The LAB colony forming units were enumerated on plates that yielded 30-300 cfu.

\section{Statistical Analysis}

Data $(n=150)$ pertaining to the inoculum application (CONT, $n=75 ; \mathrm{LH}, n=75)$, the DM content and time of conservation were compared. The data were divided into three classes of DM content, that is, low DM ( $<33 \%$ DM, $n=43)$, medium DM 
(33-38\% DM, $n=58)$ and high DM (>38\% DM, $n=49)$. Moreover, the data were divided into four classes of conservation times, that is, very short ( $<15$ days, $n=36$ ), short (15-30 days, $n=42)$, medium (31-120 days, $n=42)$ and long ( $>120$ days, $n=30)$. The nitrate content was corrected for the dilution factor and expressed on a DM basis. The microbial counts were $\log _{10}$ transformed and presented on a wet weight basis. The values below the detection limit for yeast and mold (detection level: $10 \mathrm{cfu} / \mathrm{g}$ of silage) were assigned a value corresponding to half of the detection limit to calculate the average value. An unpaired $t$-test was used to analyze the effect of inoculum application on the fermentative characteristics, microbial counts, chemical characteristics, and aerobic stability. One-way analysis of variance was used to analyze the effect of the conservation time and DM content on the fermentative characteristics, microbial counts, chemical characteristics, and aerobic stability. The data were analyzed using the General Linear Model of the Statistical Package for Social Science (v 26.0, SPSS Inc., Chicago, Illinois, the United States). When the calculated values of $F$ were significant, the Tukey post hoc test $(P<0.05)$ was used to interpret any significant differences among the mean values. Multiple regression analysis was used to correlate the acetic acid concentration, yeast count and aerobic stability values with the days of conservation (DAY), silage DM concentration, and treatment (inoculation with $\mathrm{LH}$ ), using the Draper and Smith (1998) stepwise selection procedure to select the best regression model at a 0.05 probability level. All the determination coefficients $\left(\mathrm{r}^{2}\right.$ or $\left.\mathrm{R}^{2}\right)$ reported in this paper were adjusted for degrees of freedom. The data were analyzed across experiments for regression analysis using SPSS v. 26.

\section{RESULTS}

The chemical and microbial characteristics of the corn at ensiling are reported in Table $\mathbf{1}$. The DM content of the silages ranged

TABLE 1 | Chemical and microbial characteristics of corn silages at ensiling.

\begin{tabular}{lcccc}
\hline Items & Mean & SD & Min & Max \\
\hline DM (\%) & 34.7 & 5.81 & 25.2 & 45.1 \\
$\mathrm{pH}$ & 5.72 & 0.34 & 5.54 & 6.03 \\
$\mathrm{NO}_{3}$ (mg/kg DM) & $<100$ & 61 & $<100$ & 156 \\
$\mathrm{a}_{\text {w }}$ & 0.992 & 0.006 & 0.981 & 0.999 \\
Buffering capacity (meq/kg DM) & 44 & 15 & 23 & 69 \\
Yeast (log cfu/g) & 6.72 & 0.27 & 6.03 & 7.37 \\
Mold (log cfu/g) & 5.40 & 0.48 & 4.54 & 6.65 \\
Lactic acid bacteria (log cfu/g) & 7.76 & 0.76 & 5.63 & 8.74 \\
Crude protein (\% DM) & 7.1 & 0.86 & 5.8 & 8.3 \\
Ash (\% DM) & 4.5 & 0.90 & 2.8 & 5.7 \\
Starch (\% DM) & 30.5 & 4.20 & 21.7 & 37.2 \\
NDF (\% DM) & 40.2 & 4.20 & 32.0 & 48.8 \\
ADF (\% DM) & 20.3 & 2.96 & 14.9 & 25.7 \\
Hemicellulose (\% DM) & 19.9 & 1.38 & 17.0 & 23.2 \\
ADL (\% DM) & 4.1 & 0.49 & 2.9 & 5.0 \\
\hline
\end{tabular}

$A D F$, acid detergent fiber; $A D L$, lignin; $a_{w}$, activity water; cfu, colony forming unit; $D M$, dry matter; NDF, neutral detergent fiber; $S D$, standard deviation. from 25.2 to $45.1 \%$. The $\mathrm{pH}$ was typical of corn at harvesting, with a mean value of 5.72. $\mathrm{a}_{\mathrm{w}}$ and the buffering capacity ranged from 0.981 to 0.999 and from 23 to $69 \mathrm{meq} / \mathrm{kg} \mathrm{DM}$, respectively. The yeast, mold and LAB counts were on average 6.72, 5.40, and 7.76 $\log \mathrm{cfu} / \mathrm{g}$, respectively. The nutritional composition of the silages showed a high variability, with starch and NDF ranging from 22 to $37 \% \mathrm{DM}$, and from 32 to $49 \% \mathrm{DM}$, respectively.

The Pearson correlation coefficients of the chemical, fermentative and microbial characteristics of the corn silages are reported in Table 2 . The length of conservation was positively correlated with the $\mathrm{pH}$, lactic and acetic acids, 1,2propanediol, and DM losses. On the other hand, it was negatively correlated with the microbial counts (yeast, mold, and lactic acid bacteria) and fiber component of the silages (NDF, ADF, and hemicellulose). Negative correlations were detected between the DM content and lactic and acetic acids, aerobic stability, and nutritional parameters, except for starch. The DM content was positively correlated with the yeast and mold counts, and starch content. The $\mathrm{pH}$ was strongly negatively correlated with the lactic acid content and positively with the LAB count. Acetic acid was negatively correlated with the yeast and mold counts. The DM losses were found to be correlated positively to the days of conservation and to the DM content.

The chemical, fermentative and microbial characteristics of the corn silages, untreated or treated with $L$. hilgardii, are reported in Table 3. The application of inoculum determined higher amounts of acetic acid $(P=0.013)$ and a lower lactic-toacetic ratio than CONT. 1,2-propanediol was higher in $\mathrm{LH}$ than in CONT $(P<0.001)$. The yeast count was lower $(P=0.021)$ and aerobic stability was higher $(P=0.044)$ in LH than in CONT. The DM losses during fermentation and the nutritional parameters were not affected by the application of inoculum. All the other nutritional characteristics of the silages resulted to be unaffected by the LH inoculum.

The chemical, fermentative and microbial characteristics of the corn silages for the three classes of DM content are reported in Table 4. The DM content influenced the concentration of fermentative products to a great extent, with a decrease in the lactic and acetic acids from low to high DM silages $(P<0.001)$, even though the $\mathrm{pH}$ remained almost constant. On the other hand, the ethanol content increased from low to high DM silages $(P<0.001)$. The yeast count was higher in the high DM silages than in the low DM ones ( 4.15 vs. $2.17 \log \mathrm{cfu} / \mathrm{g})$, and the aerobic stability was higher in the low DM silages than in the medium and high DM ones. The LAB counts decreased slightly as the DM content increased. The high DM silages showed lower $(P<0.001)$ NDF, ADF, hemicellulose and crude protein contents and a higher starch content $(P<0.001)$ than the low DM ones.

The chemical, fermentative and microbial characteristics of the corn silages for the four classes of days of conservation are reported in Table 5. The $\mathrm{pH}$ decreased as the length of conservation increased $(P<0.001)$. The lactic and acetic acid contents were higher for the Long conservation period than for the shorter period, whereas the lactic-to-acetic ratio decreased as the conservation period increased. 1,2-propanediol was higher than $1.0 \mathrm{~g} / \mathrm{kg} \mathrm{DM}$ after 30 days of conservation. The yeast and LAB counts decreased as the conservation period 


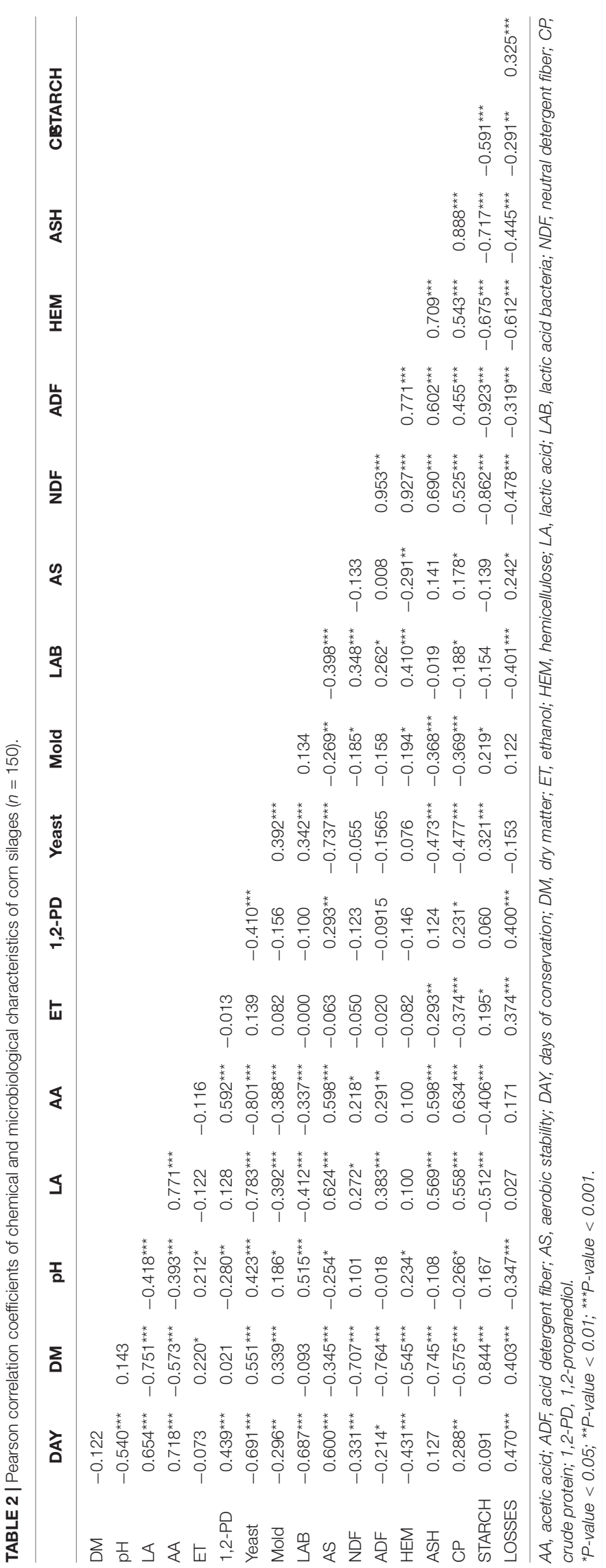

TABLE 3 | Chemical, fermentative and microbiological characteristics of corn silages as affected by inoculum.

\begin{tabular}{lcccc}
\hline Items & CONT & LH & SEM & $P$-value \\
\hline & $\boldsymbol{n}=\mathbf{7 5}$ & $\boldsymbol{n}=\mathbf{7 5}$ & & \\
DM (\%) & 36.4 & 36.2 & 0.438 & 0.718 \\
pH & 3.76 & 3.77 & 0.006 & 0.297 \\
Lactic acid (g/kg DM) & 49.7 & 49.6 & 1.070 & 0.991 \\
Acetic acid (g/kg DM) & 11.9 & 13.7 & 0.377 & 0.013 \\
Lactic-to-acetic ratio & 4.3 & 3.8 & 0.060 & $<0.001$ \\
Ethanol (g/kg DM) & 11.8 & 12.3 & 0.313 & 0.413 \\
1,2-Propanediol (g/kg DM) & 0.1 & 1.3 & 0.127 & $<0.001$ \\
Yeast (log cfu/g) & 3.35 & 2.83 & 0.114 & 0.021 \\
Mold (log cfu/g) & $<1.00$ & $<1.00$ & - & - \\
LAB (log cfu/g) & 7.43 & 7.88 & 0.075 & 0.002 \\
Aerobic stability (h) & 96 & 116 & 5.005 & 0.044 \\
DM losses (\%) & 2.21 & 2.35 & 0.047 & 0.129 \\
Crude protein (\% DM) & 7.5 & 7.6 & 0.082 & 0.797 \\
Ash (\% DM) & 4.6 & 4.8 & 0.096 & 0.290 \\
Starch (\% DM) & 34.0 & 33.7 & 0.327 & 0.729 \\
NDF (\% DM) & 38.0 & 38.7 & 0.361 & 0.318 \\
ADF (\% DM) & 19.8 & 20.2 & 0.212 & 0.367 \\
Hemicellulose (\% DM) & 18.2 & 18.5 & 0.171 & 0.324 \\
\hline ADF acid & & & & \\
\hline
\end{tabular}

$\overline{A D F}$, acid detergent fiber; cfu, colony forming unit; $D M$, dry matter; $L A B$, lactic acid bacteria; NDF, neutral detergent fiber; SEM, standard error of the mean.

TABLE 4 | Chemical, fermentative and microbiological characteristics of corn silages as affected by DM content.

\begin{tabular}{|c|c|c|c|c|c|}
\hline Items & $\begin{array}{c}\text { Low DM } \\
<33 \%\end{array}$ & $\begin{array}{c}\text { Medium DM } \\
33-38 \%\end{array}$ & $\begin{array}{c}\text { High DM } \\
>38 \%\end{array}$ & SEM & $P$-value \\
\hline & $n=43$ & $n=58$ & $n=49$ & & \\
\hline DM (\%) & $29.4^{\mathrm{C}}$ & $36.2^{b}$ & $42.4^{a}$ & 0.438 & $<0.001$ \\
\hline $\mathrm{pH}$ & 3.75 & 3.77 & 3.76 & 0.006 & 0.223 \\
\hline Lactic acid (g/kg DM) & $61.5^{\mathrm{a}}$ & $49.1^{b}$ & $39.9^{c}$ & 1.070 & $<0.001$ \\
\hline Acetic acid (g/kg DM) & $15.8^{\mathrm{a}}$ & $13.6^{\mathrm{b}}$ & $9.2^{\mathrm{C}}$ & 0.377 & $<0.001$ \\
\hline Lactic-to-acetic ratio & $4.0^{b}$ & $3.8^{b}$ & $4.5^{\mathrm{a}}$ & 0.060 & $<0.001$ \\
\hline Ethanol (g/kg DM) & $10.9^{\mathrm{b}}$ & $10.7^{b}$ & $14.8^{\mathrm{a}}$ & 0.313 & $<0.001$ \\
\hline $\begin{array}{l}\text { 1,2-Propanediol (g/kg } \\
\text { DM) }\end{array}$ & 0.57 & 0.95 & 0.54 & 0.127 & 0.316 \\
\hline Yeast (log cfu/g) & $2.17^{\mathrm{C}}$ & $2.88^{b}$ & $4.15^{\mathrm{a}}$ & 0.114 & $<0.001$ \\
\hline Mold (log cfu/g) & $<1.00$ & $<1.00$ & 1.39 & - & - \\
\hline LAB (log cfu/g) & $7.94^{\mathrm{a}}$ & $7.66^{a b}$ & $7.39^{b}$ & 0.075 & 0.018 \\
\hline Aerobic stability (h) & $141^{\mathrm{a}}$ & $97^{\mathrm{b}}$ & $85^{\mathrm{b}}$ & 5.005 & $<0.001$ \\
\hline DM losses (\%) & $2.09^{b}$ & $2.09^{b}$ & $2.68^{a}$ & 0.047 & $<0.001$ \\
\hline Crude protein (\% DM) & $8.0^{\mathrm{a}}$ & $8.0^{\mathrm{a}}$ & $6.2^{b}$ & 0.082 & $<0.001$ \\
\hline Ash (\% DM) & $5.3^{\mathrm{a}}$ & $5.1^{\mathrm{a}}$ & $2.9^{b}$ & 0.096 & $<0.001$ \\
\hline Starch (\% DM) & $29.9^{c}$ & $34.6^{b}$ & $37.8^{\mathrm{a}}$ & 0.327 & $<0.001$ \\
\hline NDF (\% DM) & $41.6^{\mathrm{a}}$ & $38.3^{b}$ & $33.9^{c}$ & 0.361 & $<0.001$ \\
\hline ADF (\% DM) & $22.4^{\mathrm{a}}$ & $19.4^{b}$ & $17.8^{\mathrm{C}}$ & 0.212 & $<0.001$ \\
\hline Hemicellulose (\% DM) & $19.3^{a}$ & $18.9^{a}$ & $16.1^{\mathrm{b}}$ & 0.171 & $<0.001$ \\
\hline
\end{tabular}

Means within a row with different superscripts differ $(P<0.05)$.

$A D F$, acid detergent fiber; cfu, colony forming unit; $D M$, dry matter; $L A B$, lactic acid bacteria; NDF, neutral detergent fiber; SEM, standard error of the mean.

increased, and the aerobic stability increased from 62 to $159 \mathrm{~h}$. The DM losses increased as the conservation period increased, and indirectly influenced the increase in the crude protein, 
TABLE 5 | Chemical, fermentative and microbiological characteristics of corn silages as affected by time of conservation.

\begin{tabular}{|c|c|c|c|c|c|c|}
\hline Items & $\begin{array}{l}\text { Very short } \\
<15 \text { days }\end{array}$ & $\begin{array}{c}\text { Short } \\
15-30 \\
\text { days }\end{array}$ & $\begin{array}{c}\text { Medium } \\
31-120 \\
\text { days }\end{array}$ & $\begin{array}{l}\text { Long } \\
>120 \\
\text { days }\end{array}$ & SEM & $P$-value \\
\hline & $n=36$ & $n=42$ & $n=42$ & & & \\
\hline DM (\%) & 35.6 & 37.2 & 36.6 & 35.3 & 0.438 & 0.419 \\
\hline $\mathrm{pH}$ & $3.82^{a}$ & $3.78^{\mathrm{b}}$ & $3.73^{\mathrm{c}}$ & $3.71^{\mathrm{c}}$ & 0.006 & $<0.001$ \\
\hline Lactic acid (g/kg DM) & $41.2^{c}$ & $44.5^{\mathrm{C}}$ & $51.8^{b}$ & $63.9^{a}$ & 1.070 & $<0.001$ \\
\hline Acetic acid (g/kg DM) & $9.4^{\mathrm{C}}$ & $10.7^{\mathrm{c}}$ & $13.9^{b}$ & $18.0^{\mathrm{a}}$ & 0.377 & $<0.001$ \\
\hline Lactic-to-acetic ratio & & & & & 0.060 & $<0.001$ \\
\hline Ethanol (g/kg DM) & $11.0^{\mathrm{b}}$ & $11.8^{a b}$ & $12.1^{\mathrm{ab}}$ & $13.8^{\mathrm{a}}$ & 0.313 & 0.030 \\
\hline $\begin{array}{l}\text { 1,2-Propanediol (g/kg } \\
\text { DM) }\end{array}$ & & $0.23^{b c}$ & & & 0.127 & $<0.001$ \\
\hline Yeast (log cfu/g) & $4.08^{a}$ & $3.44^{\mathrm{ab}}$ & $2.90^{b}$ & $1.68^{\mathrm{C}}$ & 0.114 & $<0.001$ \\
\hline Mold (log cfu/g) & 1.45 & 1.09 & $<1.00$ & $<1.00$ & - & - \\
\hline LAB (log cfu/g) & $8.41^{a}$ & $8.19^{a}$ & $7.16^{\mathrm{b}}$ & $6.72^{\mathrm{C}}$ & 0.075 & $<0.001$ \\
\hline Aerobic stability (h) & $62^{a}$ & $87^{a}$ & $125^{\mathrm{b}}$ & $159^{c}$ & 5.005 & $<0.001$ \\
\hline DM losses (\%) & $1.95^{\mathrm{C}}$ & $2.05^{\mathrm{c}}$ & $2.41^{b}$ & $2.84^{\mathrm{a}}$ & 0.047 & $<0.001$ \\
\hline Crude protein (\% DM) & $7.2^{\mathrm{b}}$ & $7.5^{\mathrm{b}}$ & $7.6^{a b}$ & $8.1^{a}$ & 0.082 & 0.025 \\
\hline Ash (\% DM) & 4.5 & 4.6 & 4.7 & 5.0 & 0.096 & 0.389 \\
\hline Starch (\% DM) & 33.9 & 33.5 & 33.9 & 34.1 & 0.327 & 0.906 \\
\hline NDF (\% DM) & $39.9^{a}$ & $38.6^{a b}$ & $38.2^{a b}$ & $36.2^{b}$ & 0.361 & 0.006 \\
\hline ADF (\% DM) & 20.7 & 19.9 & 19.9 & 19.3 & 0.212 & 0.176 \\
\hline Hemicellulose (\% DM) & $19.3^{a}$ & $18.7^{\mathrm{a}}$ & $18.2^{\mathrm{a}}$ & $16.9^{b}$ & 0.171 & $<0.001$ \\
\hline
\end{tabular}

Means within a row with different superscripts differ $(P<0.05)$.

$A D F$, acid detergent fiber; cfu, colony forming unit; $D M$, dry matter; $L A B$, lactic acid bacteria; NDF, neutral detergent fiber; SEM, standard error of the mean.

TABLE 6 | Regression models of acetic acid, yeast count, and aerobic stability on days of conservation, dry matter content and treatment with $L$. hilgardii as independent variables.

\begin{tabular}{|c|c|c|c|c|}
\hline & Model & RMSE & Adjusted $R^{2}$ & $P$-value \\
\hline $\begin{array}{l}\text { Acetic acid } \\
\text { (g/kg DM) }\end{array}$ & $\begin{array}{l}y=16.81+0.06012 \\
\times \text { DAY }- \\
0.0071 \times \mathrm{DM}^{2}+1.731 \\
\times \text { TREAT }\end{array}$ & 2.074 & 0.798 & $<0.001$ \\
\hline $\begin{array}{l}\text { Yeast (log } \\
\text { cfu/g) }\end{array}$ & $\begin{array}{l}y=1.478-0.0084 \\
\times \text { DAY }+0.0023 \times \\
D^{2}-0.4812 \times \text { TREAT }\end{array}$ & 0.775 & 0.691 & $<0.001$ \\
\hline $\begin{array}{l}\text { Aerobic } \\
\text { stability (h) }\end{array}$ & $\begin{array}{l}y=202.3+0.3658 \\
\times \text { DAY }-3.956 \times D M+ \\
18.85 \times \text { TREAT }\end{array}$ & 44.9 & 0.462 & $<0.001$ \\
\hline
\end{tabular}

DAY, days of conservation; DM, dry matter content (\%); TREAT, treatment with L. hilgardii $(0=$ not treated; 1 = treated); RMSE, root mean square error.

whereas hemicelluloses decreased and determined a reduction in the NDF content.

The acetic acid, yeast count and aerobic stability regression models, are reported in Table 6 with the days of conservation (DAY), DM content (linear or quadratic, DM or $\mathrm{DM}^{2}$ ) and treatment with L. hilgardii $(0=$ untreated; $1=$ treated with $\mathrm{LH})$ as the independent variables. The acetic acid content and yeast count of the silages were influenced by the days of conservation, $\mathrm{DM}^{2}$ and treatment, with adjusted coefficients of determination of 0.798 and 0.691 , respectively. The application of the $\mathrm{LH}$ inoculum determined an increase in the acetic acid $(1.73 \mathrm{~g} / \mathrm{kg}$ $\mathrm{DM})$ and a reduction of the yeast count of $0.48 \mathrm{log} \mathrm{cfu} / \mathrm{g}$. The days of conservation influenced the aerobic stability (about $3.7 \mathrm{~h}$ for each further 10 days of conservation) and the treatment with $\mathrm{LH}$ on average increased for $18.9 \mathrm{~h}$ of aerobic stability. On the other hand, the DM content of the silage determined a reduction of 39.6 h every $10 \%$ units of increase of DM.

The acetic acid content, yeast count and aerobic stability, as affected by the treatment with L. hilgardii, the DM content and the days of conservation are shown in Figures 1-3, respectively. Acetic acid was influenced by the LH treatment and shows an interaction with the DM and DAY of conservation. The yeast count decreased during conservation, with lower values in low DM silages than in high DM silages, while the silages inoculated with $\mathrm{LH}$ presented lower values than $\mathrm{C}(P<0.001)$. Aerobic stability was higher in the treated silages than in the untreated ones, higher in the low DM silages than the high DM ones, and higher in the long conservation periods than the short ones $(P<0.001)$.

\section{DISCUSSION}

The present study indicated that the aerobic stability of silage is closely related to the yeast count and, albeit indirectly, to the antifungal activity of acetic acid, and that several interacting factors can influence its magnitude. Heterofermentative LAB inocula have been developed to reduce the yeast count over conservation and to slow down or to inhibit their activity after silo opening, thus improving the aerobic stability of silages (Muck et al., 2018). LAB strains selection is based on their ability to fast growth and to compete with epiphytic microorganisms especially under sub-optimal conditions (e.g., high DM content or low temperature). However, a notable change in LAB composition have been detected during the first fermentation phase (Drouin et al., 2019), and many of the inocula strains are not fast in dominating the fermentation. Under farm conditions, corn is often harvested when the plants are lower or higher in DM than the optimal concentration (from 30 to $38 \%$ DM) due to an inadequate capacity to harvest large amounts of forage over a short period of time (Windle et al., 2014). Furthermore, several farmers choose to harvest corn at high concentrations of DM to obtain higher yields and starch concentrations. However, this leads to greater packing difficulties and the resulting silage often spoils rapidly when exposed to air (Comino et al., 2014; Windle et al., 2014). A high DM content, because of a reduced $\mathrm{a}_{\mathrm{w}}$, limits the LAB activity, with a consequent reduction in volatile fatty acid production (Comino et al., 2014), and in particular of acetic acid, which is known to strongly contrast yeast activity in the presence of air. In our experiment, a restriction of fermentation was observed from wetter to drier silages, with the latter having lower acetic acid concentrations than $10 \mathrm{~g} / \mathrm{kg}$ DM. This finding is in agreement with the results of Der Bedrosian et al. (2012), who reported that the concentration of acetic acid was higher $(14.2 \mathrm{~g} / \mathrm{kg} \mathrm{DM})$ in $32 \% \mathrm{DM}$ than in $41 \% \mathrm{DM}(11.6 \mathrm{~g} / \mathrm{kg} \mathrm{DM})$ corn silage, and of those of Comino et al. (2014), who found a progressive restriction of acetic acid production in corn silage of 


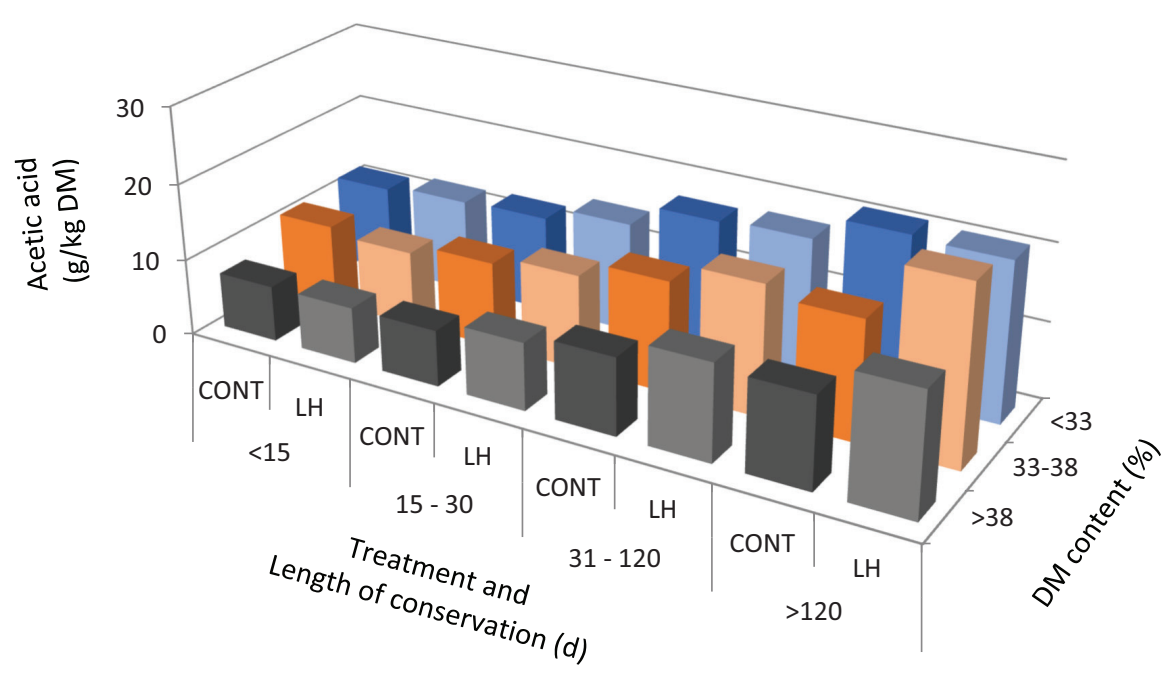

FIGURE 1 | The acetic acid content as affected by treatment with Lentilactobacillus hilgardii, DM content and days of conservation.

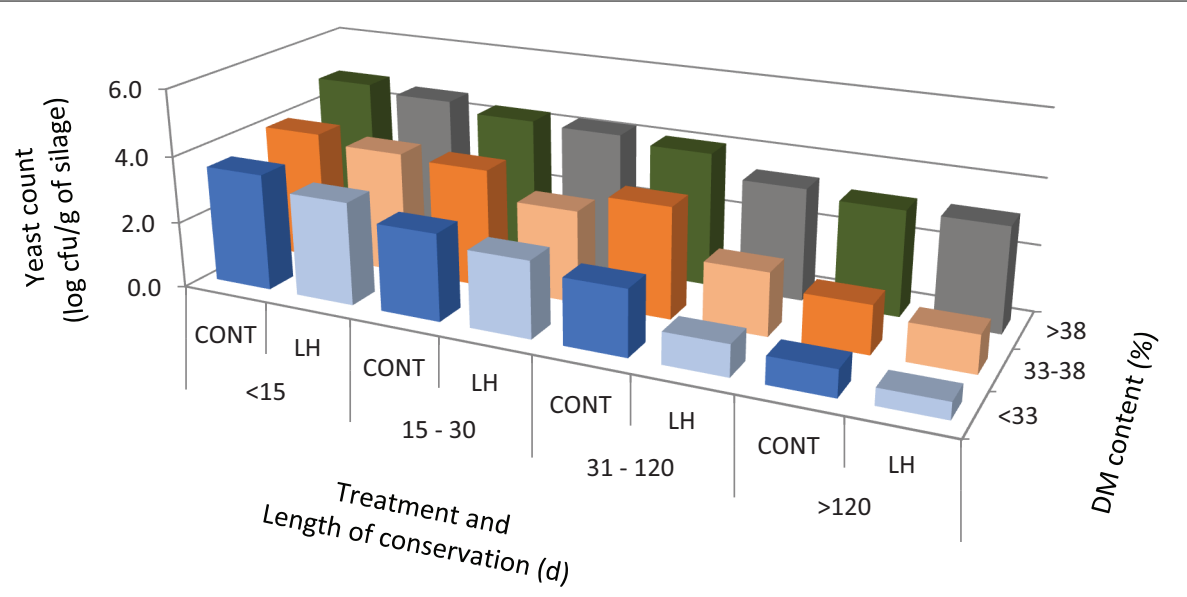

FIGURE 2 | The yeast count as affected by treatment with Lentilactobacillus hilgardii, DM content and days of conservation.

more than $20 \mathrm{~g} / \mathrm{kg}$ DM when the DM content increased from 26 to $43 \%$. Lower concentrations of acetic acid in high DM corn silages are considered to be one of the factors that contribute the most to explaining why these silages tend to be less aerobically stable than low DM corn silages (Der Bedrosian et al., 2012). In the present experiment, the lower amount of acetic acid in silages with a higher DM content than $38 \%$ resulted in a higher yeast count than $4 \mathrm{log} \mathrm{cfu} / \mathrm{g}$. Therefore, in these silages, the aerobic stability was lower than the aerobic stability observed for wetter silages.

Aerobic stability can also be influenced to a great extent by the conservation time. A long conservation period in complete anaerobiosis has been reported to determine a decrease in the yeast count (Weinberg and Chen, 2013; Ferrero et al., 2019). Weinberg and Chen (2013) analyzed the fermentation profile and microbial count of corn silages opened after 1 week to 12 months of conservation. They found an increase in acetic acid of $8-47 \mathrm{~g} / \mathrm{kg}$ DM, which resulted in a decrease in the yeast count and an improvement in aerobic stability. The same trend pertaining to an acetic acid increase, yeast count decrease and aerobic stability increase was reported by Kleinschmidt and Kung (2006), who investigated untreated corn ensiled at $37 \%$ DM, over an ensiling period of 14-361 days. Furthermore, Der Bedrosian et al. (2012) reported that the acetic acid content increased steadily in untreated corn silage with the length of storage, from $9.8 \mathrm{~g} / \mathrm{kg}$ DM after 45 days of ensiling to $17.1 \mathrm{~g} / \mathrm{kg}$ DM after 360 days of ensiling. In agreement with the paper mentioned above (Kleinschmidt and Kung, 2006; Der Bedrosian et al., 2012), a long conservation period in the current experiment resulted in an increase in acetic acid content, a reduction in the yeast count and an improvement in aerobic stability. These effects were more evident in the wetter silages than in the drier ones, thus highlighting a positive synergistic effect between the DM of silage and the length of the conservation period. The wetter silages 


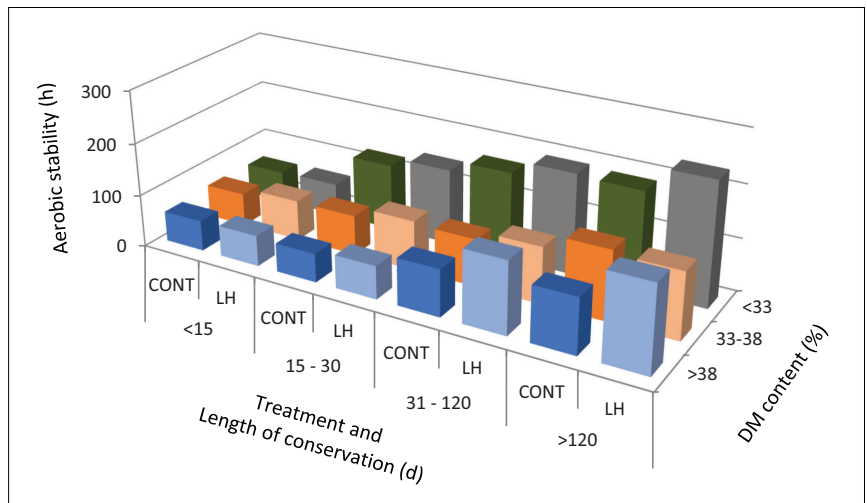

FIGURE 3 | The aerobic stability as affected by treatment with Lentilactobacillus hilgardii, DM content and days of conservation.

therefore had a lower yeast count and higher aerobic stability than the drier silages for a given length of conservation. This is in agreement with the results of Ferrero et al. (2021) who observed, on corn silages ensiled at 42\% DM from 15 to 100 days, that the reduction in the yeast count and the increase in aerobic stability during conservation was less marked than in another experiments (Ferrero et al., 2019) in which corn silages were ensiled, for the same conservation periods but at lower DM contents (36.3 and 34.0\%).

Several authors have reported that the heterofermentative LAB L. buchneri (the most frequently used heterofermentative LAB inoculum) does not show a consistent effect on corn silages after shorter periods of conservation than 45-60 days (Driehuis et al., 1999; Kleinschmidt and Kung, 2006; Ferrero et al., 2019) or on silages with a higher DM than 38\% ( $\mathrm{Hu}$ et al., 2009; Comino et al., 2014; Xu et al., 2019). To overcome this drawback, recent research has been directed toward finding heterofermentative Lactobacillus strains which are able to work rapidly after silo closure. A strain of L. hilgardii was isolated from sugarcane silage in Brazil (Ávila et al., 2014) and was produced and industrialized to be active after a short conservation period. Reis et al. (2018) found an increase in acetic acid content after 19 days of ensiling corn silage, but these authors did not perform an aerobic stability test. The same authors however found an increase in aerobic stability in silages treated with $\mathrm{LH}$ after 103 days of conservation (Reis et al., 2018). In the study of Ferrero et al. (2019), the addition of $\mathrm{LH}$ alone increased the aerobic stability in one out of two corn silage trials, with higher aerobic stabilities observed after 15 and 30 days of conservation. Drouin et al. (2019) found a higher acetic acid production in silages treated with $\mathrm{LH}$ than in uninoculated ones already after the first day of ensiling. Costa et al. (2021) found that silages treated with L. hilgardii had higher aerobic stability, and lower numbers of yeasts than untreated ones. Ferrero et al. (2021) did not find any differences after 15 or 30 days of conservation between treated and untreated silages, probably because of the DM content of the silages was higher than $40 \%$. In our experiment, L. hilgardii was able to dominate the fermentation and to modify the fermentation profile, with a high production of acetic acid and 1,2-propanediol, which is the typical end-product of L. buchneri group bacteria (Oude Elferink et al., 2001; Muck et al., 2018). This fermentative profile resulted in a reduction in the yeast count and an average increase in aerobic stability of $20 \mathrm{~h}$, compared to the untreated silages.

In the present paper, we performed a regression model with the days of conservation, the DM content and inoculation with L. hilgardii to correlate the acetic acid content, yeast count and aerobic stability. Acetic acid has been found to increase as the conservation period increases and to decrease as the DM content increases. This can be explained by the fact that heterolactic bacteria act after homolactic ones, and their activity is less marked in high DM silages (Pahlow et al., 2003). The inoculation with LH determined an increase in the acetic acid $(+1.73 \mathrm{~g} / \mathrm{kg} \mathrm{DM})$. As expected, the yeast count was reduced as the time of conservation increased in a DM dependent manner, and the inoculation with LH determined an average reduction of the count of $0.48 \mathrm{log}$ $\mathrm{cfu} / \mathrm{g}$. The aerobic stability increased by about $3.7 \mathrm{~h}$ for every 10 days of conservation, and on average by $18.9 \mathrm{~h}$ for the $\mathrm{LH}$ treatment, whereas it decreased for an increasing DM content of the silages, as already discussed above, and as reported by several authors (Comino et al., 2014; Ferrero et al., 2021).

The treatment with $L$. hilgardii did not show any differences in the nutritional composition of the silages. On the other hand, the DM content influenced the composition of the corn silage to a great extent. As expected, the increase in the DM content of silage determined an increase in the starch content and a reduction in the NDF content. This can be useful for animal nutrition as starch represents a source of energy for dairy and beef cattle. However, no changes were observed during conservation, although it has been reported that starch degradability increases during storage in corn silages with a high DM content, and that starch degradability increases during storage (Hoffman et al., 2011; Gerlach et al., 2018).

The results of this experiment suggest that higher aerobic stability could be achieved in corn silages by ensiling at medium or low DM contents, or by increasing the length of conservation if a higher DM content at ensiling is needed. The results also suggest that inoculation with L. hilgardii helps to improve the aerobic stability of corn silages by enhancing the production of acetic acid, which determines a greater reduction in the yeast counts than those observed in uninoculated silages. The best results have been found in medium DM content silages (i.e., 33-38\% DM) and for microbiological stabilized silages (after a medium to long conservation period in complete anaerobiosis, i.e., $>30$ days). Further study will be needed to evaluate the effect of DM content, length of conservation and treatment with L. hilgardii under farm conditions.

\section{DATA AVAILABILITY STATEMENT}

The raw data supporting the conclusions of this article will be made available by the authors, without undue reservation.

\section{AUTHOR CONTRIBUTIONS}

FF, ET, and GB conceived and designed the experiments. ET and FF analyzed the data. FF wrote the original draft of the 
manuscript. ET and GB wrote, reviewed, and edited the maunscript. GB supervised, administered the project, and acquired funding. All authors performed the experiments.

\section{FUNDING}

Mention of trade names or commercial products in this article is solely for the purpose of providing specific information and does not imply either recommendation or endorsement by the University of Turin, Italy. Research is supported in

\section{REFERENCES}

AOAC International (2005). Official Methods of Analysis, 18th Edn. Gaithersburg, MD: AOAC International.

Assis, F. G. D., Avila, C. L. D., Pinto, J. C., and Schwan, R. F. (2014). New inoculants on maize silage fermentation. Rev. Bras. Zoot. 43, 395-403. doi: 10.1590/s151635982014000800001

Ávila, C. L. S., Carvalho, B. F., Pinto, J. C., Duarte, W. F., and Schwan, R. F. (2014). The use of Lactobacillus species as starter cultures for enhancing the quality of sugar cane silage. J. Dairy Sci. 97, 940-951. doi: 10.3168/jds.20136987

Blajman, J. E., Páez, R. B., Vinderola, C. G., Lingua, M. S., and Signorini, M. L. (2018). A meta-analysis on the effectiveness of homofermentative and heterofermentative lactic acid bacteria for corn silage. J. Appl. Microbiol. doi: 10.1111/jam.14084 Online ahead of print.

Borreani, G., Tabacco, E., Schmidt, R. J., Holmes, B. J., and Muck, R. E. (2018). Silage review: factors affecting dry matter and quality losses in silages. J. Dairy Sci. 101, 3952-3979. doi: 10.3168/jds.2017-13837

Canale, A., Valente, M. E., and Ciotti, A. (1984). Determination of volatile carboxylic acids (C1-C5) and lactic acid in aqueous acid extracts of silage by high performance liquid chromatography. J. Sci. Food Agric. 35, 1178-1182. doi: $10.1002 /$ jsfa.2740351106

Comino, L., Tabacco, E., Righi, F., Revello-Chion, A., Quarantelli, A., and Borreani, G. (2014). Effects of an inoculant containing a Lactobacillus buchneri that produces ferulate-esterase on fermentation products, aerobic stability, and fibre digestibility of maize silage harvested at different stages of maturity. Anim. Feed Sci. Technol. 198, 94-106. doi: 10.1016/j.anifeedsci.2014.10.001

Costa, D. M., Carvalho, B. F., Bernardes, T. F., Schwan, R. F., and Ávila, C. L. S. (2021). New epiphytic strains of lactic acid bacteria improve the conservation of corn silage harvested at late maturity. Anim. Feed Sci. Technol. 274:114852. doi: 10.1016/j.anifeedsci.2021.114852

Der Bedrosian, M. C., Nestor, K. E., and Kung, L. (2012). The effects of hybrid, maturity, and length of storage on the composition and nutritive value of corn silage. J. Dairy Sci. 95, 5115-5126. doi: 10.3168/jds.2011-4833

Draper, N. R., and Smith, H. (1998). Applied Regression Analysis, 3rd Edn. New York: John Wiley \& Sons.

Driehuis, F., Elferink, S., and Spoelstra, S. F. (1999). Anaerobic lactic acid degradation during ensilage of whole crop maize inoculated with Lactobacillus buchneri inhibits yeast growth and improves aerobic stability. J. Appl. Microbiol. 87, 583-594. doi: 10.1046/j.1365-2672.1999.00856.x

Driehuis, F., Wilkinson, J. M., Jiang, Y., Ogunade, I., and Adesogan, A. T. (2018). Silage review: animal and human health risks from silage. J. Dairy Sci. 1, 4093-4110. doi: 10.3168/jds.2017-13836

Drouin, P., Tremblay, J., and Chaucheyras-Durand, F. (2019). Dynamic succession of microbiota during ensiling of whole plant corn following inoculation with Lactobacillus buchneri and Lactobacillus hilgardii alone or in combination. Microorganisms 7:595. doi: 10.3390/microorganisms7120595

Ferrero, F., Piano, S., Tabacco, E., and Borreani, G. (2019). Effects of conservation period and Lactobacillus hilgardii inoculum on the fermentation profile and aerobic stability of whole corn and sorghum silages. J. Sci. Food Agric. 99, 2530-2540. doi: 10.1002/jsfa.9463

Ferrero, F., Tabacco, E., Piano, S., Casale, M., and Borreani, G. (2021). Temperature during conservation in laboratory silos affects fermentation profile and part by a generous grant from Danstar Ferment AG (Zug, Switzerland).

\section{ACKNOWLEDGMENTS}

We thank Mauro Gilli and Mario Gilardi [Department of Agricultural, Forest and Food Sciences (DISAFA), University of Turin, Italy] for technical assistance in the field and Serenella Piano and Manuela Casale (DISAFA) for the chemical and microbiological analyses.

aerobic stability of corn silage treated with L. buchneri, L. hilgardii and their combination. J. Dairy Sci. 104, 1696-1713. doi: 10.3168/jds.202018733

Gerlach, K., Pfau, F., Pries, M., Hünting, K., Weiß, K., Richardt, W., et al. (2018). Effects of length of ensiling and maturity group on chemical composition and in vitro ruminal degradability of whole-crop maize. Grass Forage Sci. 73, 599-609. doi: 10.1111/gfs. 12362

Heinl, S., Wibberg, D., Eikmeyer, F., Szczepanowski, R., Blom, J., Linke, B., et al. (2012). Insights into the completely annotated genome of Lactobacillus buchneri CD034, a strain isolated from stable grass silage. J. Biotechnol. 161, 153-166. doi: 10.1016/j.jbiotec.2012.03.007

Hoffman, P. C., Esser, N. M., Shaver, R. D., Coblentz, W., Scott, M. P., Bodnar, A. L., et al. (2011). Influence of ensiling time and inoculation on alteration of the starch-protein matrix in high-moisture corn. J. Dairy Sci. 94, 2465-2474. doi: 10.3168/jds.2010-3562

Hu, W., Schmidt, R. J., McDonell, E. E., Klingerman, C. M., and Kung, L. (2009). The effect of Lactobacillus buchneri 40788 or Lactobacillus plantarum MTD1 on the fermentation and aerobic stability of corn silages ensiled at two dry matter contents. J. Dairy. Sci. 92, 3907-3914. doi: 10.3168/jds.2008-1788

Kleinschmidt, D. H., and Kung, L. (2006). A meta-analysis of the effects of Lactobacillus buchneri on the fermentation and aerobic stability of corn and grass and small-grain silages. J. Dairy Sci. 89, 4005-4013. doi: 10.3168/jds. s0022-0302(06)72444-4

Muck, R. E., Nadeau, E. M. G., McAllister, T. A., Contreras-Govea, F. E., Santos, M. C., and Kung, L. (2018). Silage review: recent advances and future uses of silage additives. J. Dairy Sci. 101, 3980-4000. doi: 10.3168/jds.2017-13 839

Nair, J., Huaxin, N., Andrada, E., Yang, H., Chevaux, E., Drouin, P., et al. (2020). Effects of inoculation of corn silage with Lactobacillus hilgardii and Lactobacillus buchneri on silage quality, aerobic stability, nutrient digestibility, and growth performance of growing beef cattle. J. Anim. Sci. 98:skaa267.

Oude Elferink, S. J. W. H., Krooneman, J., Gottschal, J. C., Spoelstra, S. F., Faber, F., and Driehuis, F. (2001). Anaerobic conversion of lactic acid to acetic acid and 1,2-propanediol by Lactobacillus buchneri. Appl. Environ. Microbiol. 67, 125-132. doi: 10.1128/aem.67.1.125-132.2001

Pahlow, G., Muck, R. E., Driehuis, F., Oude Elferink, S. J. W. H., and Spoelstra, S. F. (2003). "Microbiology of ensiling," in Silage Science and Technology (Agronomy Series No. 42), eds D. R. Buxton, R. E. Muck, and H. J. Harrison (Madison, WI: American Society of Agronomy), 31-93. doi: 10.2134/agronmonogr42.c2

Playne, M. J., and McDonald, P. (1966). The buffering constituents of herbage and of silage. J. Sci. Food Agric. 17, 264-268. doi: 10.1002/jsfa.2740170609

Porter, M. G., and Murray, R. S. (2001). The volatility of components of grass silage on oven drying and the inter-relationship between dry-matter content estimated by different analytical methods. Grass Forage Sci. 56, 405-411. doi: 10.1046/j.1365-2494.2001.00292.x

Reis, C. B., de Oliveira, dos Santos, A., Carvalho, B. F., Schwan, R. F., and Ávila, C. L. D. S. (2018). Wild Lactobacillus hilgardii (CCMA 0170) strain modifies the fermentation profile and aerobic stability of corn silage. J. Appl. Anim. Res. 46, 632-638. doi: 10.1080/09712119.2017.1371609

Robertson, J. B., and Van Soest, P. J. (1981). "The detergent system of analysis and its application to human foods," in The Analysis of Dietary Fiber in Food, eds W. P. T. James and O. Theander (New York, NY: Marcel Dekker), $123-158$. 
Spoelstra, S. F., Courtin, M. G., and Van Beers, J. A. C. (1988). Acetic acid bacteria can initiate aerobic deterioration of whole crop maize silage. J. Agric. Sci. 111, 127-132. doi: 10.1017/s0021859600082915

Van Soest, P. J., Robertson, J. B., and Lewis, B. A. (1991). Methods of dietary fiber, neutral detergent fiber, and nonstarch polysaccharides in relation to animal nutrition. J. Dairy Sci. 74, 3583-3597. doi: 10.3168/jds.s0022-0302(91)78551-2

Weinberg, Z. G., and Chen, Y. (2013). Effects of storage period on the composition of whole crop wheat and corn silages. Anim. Feed Sci. Technol. 185, 196-200. doi: 10.1016/j.anifeedsci.2013.08.009

Windle, M. C., Walker, N., and Kung, L. (2014). Effects of an exogenous protease on the fermentation and nutritive value of corn silage harvested at different dry matter contents and ensiled for various lengths of time. J. Dairy Sci. 97, 3053-3060. doi: 10.3168/jds.2013-7586

Xu, S., Yang, J., Qi, M., Smiley, B., Rutherford, W., Wang, Y., and McAllister, T. A. (2019). Impact of Saccharomyces cerevisiae and Lactobacillus buchneri on microbial communities during ensiling and aerobic spoilage of corn silage. Anim. Sci. J. 97, 1273-1285. doi: 10.1093/jas/skz021
Zheng, J., Wittouck, S., Salvetti, E., Franz, C. M. A. P., Harris, H. M. B., and Mattarelli, P. (2020). A taxonomic note on the genus Lactobacillus: description of 23 novel genera, emended description of the genus Lactobacillus Beijerinck 1901, and union of Lactobacillaceae and Leuconostocaceae. Int. J. Syst. Evol. Microbiol. 70, 2782-2858. doi: 10.1099/ijsem.0.004107

Conflict of Interest: The authors declare that this study received funding from Danstar Ferment AG. The funder was not involved in the study design, collection, analysis, interpretation of data, the writing of this article or the decision to submit it for publication.

Copyright $\odot 2021$ Ferrero, Tabacco and Borreani. This is an open-access article distributed under the terms of the Creative Commons Attribution License (CC BY).

The use, distribution or reproduction in other forums is permitted, provided the original author(s) and the copyright owner(s) are credited and that the original publication in this journal is cited, in accordance with accepted academic practice. No use, distribution or reproduction is permitted which does not comply with these terms. 